\title{
THE AQUARES MODEL: DOES IT HAVE IMPACT ON IMPROVING PERSONAL AND SOCIAL RESPONSIBILITY?
}

\author{
Ermawan Susanto*, Pamuji Sukoco, Suharjana \\ Yogyakarta State University, Indonesia \\ *e-mail: ermawan@uny.ac.id
}

\begin{abstract}
Accidents in swimming pools which include drowning are more likely to happen in Indonesia. Cases of accidents in swimming pools might indicate that there may be a lack of responsibility among swimmers. Therefore, there is a need to improve this condition. The purpose of this study was to determine the impact of the Aquares model developed from Teaching Personal and Social Responsibility (TPSR) theory on the students' responsibility in swimming lessons. This study used an experimental method with one group pretest-posttest design. The study population was Grade 4 students with a sample of 60 students obtained through cluster random sampling. The instrument employed for measuring personal and social responsibility was the Tool for Assessing Responsibility-Based Education (TARE). Data collection used exploratory factor analysis. With the paired sample $t$-test analysis, the results of the study showed that Aquares model has a significant impact on the students' increased personal and social responsibility. The aspects of increased responsibility include: respect, participation, self-direction, care, and awareness of being a role model. The Aquares model applied in this study provides a strong framework for creating a meaningful and responsible environment for learning.
\end{abstract}

\section{Keywords: Aquares model, personal and social responsibility, swimming lesson}

\section{MODEL AQUARES: APAKAH BERDAMPAK PADA PENINGKATAN TANGGUNG JAWAB PRIBADI DAN SOSIAL?}

\begin{abstract}
Abstrak: Kecelakaan di kolam renang termasuk tenggelam merupakan kejadian yang sering terjadi di Indonesia. Kasus kecelakaan di kolam renang merupakan indikasi belum terbentuknya sikap tanggung jawab para perenang. Karena itu, ada kebutuhan untuk memperbaiki kondisi tersebut. Tujuan penelitian ini adalah untuk mengetahui apakah ada dampak dari model Aquares yang dikembangkan dari teori Teaching Personal and Social Responsibility (TPSR), terhadap tanggung jawab peserta didik dalam pembelajaran renang. Penelitian ini menggunakan metode eksperimen dengan desain one group pretest-posttest design. Populasi penelitian adalah peserta didik kelas IV dengan sampel 60 peserta didik diambil melalui cluster random sampling. Instrumen untuk mengukur tanggung jawab pribadi dan sosial menggunakan Tool for Assessing Responsibility-Based Education (TARE). Pengumpulan data menggunakan teknik exploratory factor analysis. Dengan analisis data paired sample t-test diketahui hasil penelitian bahwa terdapat dampak yang signifikan antara model Aquares terhadap peningkatan tanggung jawab pribadi dan sosial peserta didik dalam pembelajaran renang. Aspek tanggung jawab yang meningkat antara lain: rasa hormat, partisipasi, kemandirian, kepedulian, dan role model. Model Aquares yang diterapkan dalam penelitian ini memberikan kerangka kerja yang kuat dalam menciptakan lingkungan yang bermakna dan bertanggung jawab.
\end{abstract}

Kata Kunci: model Aquares, tanggung jawab pribadi dan sosial, pembelajaran renang

\section{INTRODUCTION}

Accidents in swimming pools may occur to everyone, both to those who are able to swim and those who are not. One type of accident that often occurs in swimming pools is drowning. Drowning is the biggest risk in aquatic activity.
Some other risks are water injury, cramps, respiratory problems, headaches, and fainting. There are several drowning case examples. Alex Aden Putra (10 years) died caused by drowning in a swimming pool at Ciputra Water Park, Surabaya (https://news.detik.com/ 
berita-jawa-timur). Hundreds of students at junior high school 1 Turi were swept away during the river alignment activity at Sempor Turi Sleman (https://www.kompas.com/tren/ $\mathrm{read} /$ ). The problem of the incidents relate to the irresponsibility either of students, teacher, or supervisors. This can be happened because the human mind is not constant from time to time, causing something dangerous for oneself and others (Kumar, Singh, Sandhu, Gupta, \& Pandey, 2017). Preliminary survey shows that $40 \%$ incidence of near drowning, occurred because of the absence of Standard Operational Procedure on safety in the pool. Based on the spot, $70 \%$ of victims drowned were occured in public pools. An alarming number of injuries and drowning events occur at lifeguarded swimming pools (Schwebel, Jones, Holder, \& Marciani, 2011). This incident is a serious problem that can threaten the health and safety of students. The phenomenon might illustrate the low level of students' personal and social responsibilities.

Swimming lesson aims to develop motoric aspects in the form of basic swimming skills and also provides students with opportunities as many as possible to be directly involved in the learning process both cognitively and affectively. However, reality in school still shows that swimming learning is about physical activity emphasizes on physicality, physical skills development, and abilities (Rahayu, Suherman, \& Jabar, 2018). Epidemiological data indicate that children are a high-risk group for drowning and while progress has been made in understanding toddler drowning, there is a lack of empirical evidence regarding the drowning risk and protective factors inherent for adolescents and young adults (Petrass \& Blitvich, 2014).

Thus the thing in swimming learning has not succeeded in realizing the full educational goals. For this reason there are specific new breakthroughs that can be used in swimming lesson to develop personal responsibility, interaction, and changes in social behavior. The model is a Teaching Personal and Social Responsibility (TPSR) developed by Hellison \& Walsh (2002). This model has a specific goal that is the emphasis on personal development and responsibility of students. The learning approach is more oriented towards student centered, namely self-actualization and social reconstruction. There has been much evidence of research results with the TPSR model which concludes that the TPSR model significantly influences the development of socially responsible attitudes and behaviors.

One model of learning that can be taken is through learning models of personal and social responsibility (Martinek \& Hellison, 2016). Hellison introduces the concept of TPSR which is one of the holistic learning models that can be used in Physical Education (PE) subjects in schools. The TPSR model aims to promote healthy motion learning and overcome risk factors and prevent problematic behavior (Anthony, Alter, \& Jenson, 2009). Based on this, PE teachers need to use appropriate instructional approaches to achieve positive results, one of which has been demonstrated internationally, namely: Teaching Personal \& Social Responsibility Model (Pozo, Grao-Cruces, \& Pérez-Ordás, 2018).

The TPSR model has been based on concepts that foster resilience, which can have a positive impact on students' future involvement (Walsh, 2008). Teachers in the implementation of teaching need to use appropriate instructional approaches such as teaching TPSR (Alcalá, Río, Calvo, \& Pueyo, 2019). The core of the TPSR model is to discuss two values of responsibility, one that focuses on personal well-being and the other on social welfare or helping others (Martinek \& Hellison, 2016). Thus, those who participate in the TPSR model learn how to develop personal and social responsibility gradually, experiencing attitudes and behaviors that help them become responsible people (Cabalero, Delgado, \& Escartí, 2013).

TPSR can provide an effective framework for promoting responsibility throughout the school curriculum (Escartí, Goig, \& Wright, 2017) including the curriculum at Primary School. It is also hoped that through this learning the increased responsibility formed in schools can be inherent and bring this to life in the community. This conclusion is supported by the results of research which shows that the TPSR model appears to promote the acquisition of social skills by encouraging students to imagine their daily activities similar to scenarios in PE, where they are encouraged to behave responsibly (Umegaki, Otomo, Minamishima, Ueta, Fukada, Yoshii, \& Miyao, 2016). The TPSR provides a clearer learning structure in PE. This is because the structure of the TPSR model specifically 
includes direct teaching, cooperative learning, and decision making (Wright, Withley, \& Sabolboro, 2012).

Early childhood education is the responsibility of all parties in relation to the effort of helping lay the foundation for childhood development in all aspects before entering school (Sutapa \& Suharjana, 2020). In the context of learning in school, an attitude of responsibility and social behavior is absolutely necessary because it will train students to fulfill their obligations as individuals and as social creatures (Glassman, Castor, Karmakar, Blavos, Dagenhard, Domigan, \& Kucharewski, 2018). Likewise in swimming lesson, it is very suitable given the content of TPSR as a learning model to develop students' responsibilities. The Aquares model is an acronym for Aquatics Responsibility, an aquatic lesson model developed to teach personal and social responsibility. The TPSR is oriented to the level of responsibility as listed in Table 1 .

Table 1. Level of Teaching Personal \& Social Responsibility (Martinek \& Hellison, 2016)

\begin{tabular}{cl}
\hline Level & Component \\
\hline $1 . \quad$ Respecting the right and feeling of others \\
Self-control \\
The right to peaceful conflict resolution \\
The right to be included \\
2. $\quad \begin{array}{l}\text { Participation and effort } \\
\text { Self-motivation }\end{array}$ \\
Exploration of effort and new tasks \\
Courage to persist when the going gets tough \\
3. Self-direction \\
On-task independence \\
Goal-setting progression \\
Courage to resist peer pressure \\
Helping others and leadership \\
Caring and compassion \\
Sensitivity and responsive \\
Inner strength \\
Outside the gym \\
Trying these ideas in other areas of life being \\
a role model
\end{tabular}

The implementation of TPSR aims to provide a variety of life skills learning and develop the physical and psychological aspect of at-risk adolescents (Wright \& Burton, 2008; Walsh, 2008). Values related to personal responsibility are effort and autonomy, while values related to social responsibility are respect for the feelings and rights of others, social empathy, and sensitivity (Escartí et al., 2017). Therefore, this research is very important to be conducted to provide empirical findings in terms of students' responsibilities. This study aims to determine the impact of giving Aquares models on the responsibilities. The responsibility variables measured include: respect, participation, selfdirection, caring, and role models.

\section{METHOD}

This research used an experimental method. The independent variable was the Aquares model and the dependent variable was personal and social responsibility. The population used in this study were students of grade $4^{\text {th }}$ Islamic primary school in Yogyakarta. The research sample consisted of 60 students and $4 \mathrm{PE}$ teachers who were selected using cluster random sampling. The research design used One-Group Pre-test Post-test Design. Instrument for measuring of personal and social responsibility used the Tool for Assessing Responsibility-Based Education/TARE (Wright $\&$ Craig, 2011). The number of questionnaire items for personal responsibility were 28 items and for social responsibility as many as 30 items with a validity level of .47 and a reliability of .98 .

Data analysis technique used exploratory factor analysis (EFA). Prior to EFA analysis, KMO and Bartlett's test and anti-image correlation analysis were performed. Data analysis used paired sample t-tests. In order to find out the responsibility variable, an inferential test was performed using paired sample t-test, while to prove the difference in the effects of the two treatments was carried out by independent sample $t$-test. Prerequisite tests included normality tests and homogeneity tests. The experimental test of the influence of the Aquares model was carried out for 10 sessions. The Aquares model material included awareness talk, lesson focus, group meetings, and reflection time. Research on the influence of the Aquares model was carried out for 10 sessions (each week, 90 minutes each). Table 2 explains the distribution of the Aquares model program outline. The treatment interventions that are given focus on questions about the level of responsibility already undertaken. 
Table 2. The Aquares Model Program Outline

\begin{tabular}{ll}
\hline $\begin{array}{c}\text { Teaching } \\
\text { Segment }\end{array}$ & Aquares Model \\
\hline Opening & Apperception \\
& Warming up \\
Core & Awareness talk \\
& Lesson focus \\
& Presented the problem related to \\
& learning material \\
& Identified the problem \\
& Data analysis \\
& Answer the problem \\
& Practicing movement \\
& Group meeting \\
Closing & Reflection time \\
& Cooling down \\
\hline
\end{tabular}

\section{RESULTS AND DISCUSSION Results}

Description of the results of research on the variable attitude of responsibility of students in swimming lesson was taken at the time of the pre-test and post-test. The pre-test results, illustrated in Table 3 shows that the average value of the attitude of responsibility of students in the Aquares model. Likewise, based on the results of the post-test were also shown, the average value of the attitude of responsibility of students in the Aquares model. There are differences in the pre test and post test scores of Aquares. To determine the variable of responsibility, an inferential test was performed using paired sample t-test, while to prove the difference in the effects of the two treatments was carried out with independent sample $t$-test.

Table 3. Descriptive Statistics for Pre-test and Post-test on the Experiments

\begin{tabular}{ccc}
\hline Pre-test & Post-test & $\begin{array}{c}\text { Differences } \\
\text { Pre-post }\end{array}$ \\
\hline $\bar{x}=2,7384$ & $\bar{x}=3,2243$ & $\bar{x}=0,4859$ \\
$S D=.55632$ & $S D=.41975$ & $S D=.1721$ \\
$N=60$ & $N=60$ & $N=60$ \\
\hline
\end{tabular}

To analyze the data, researchers used paired sample t-tests to prove the importance of the influence of the Aquares model to increase students' responsibilities. The analysis used a two-tailed test and a significance level of .05. Analysis data as illustrated in Table 4 shows that there is a significant effect of the Aquares model in increasing student responsibility ( $t=$ $6.875, p=.00<.005)$, so that the Aquares model in swimming lesson is effective for increasing students' responsibilities of primary school.

Table 4. Paired Sample t-test for Responsibility Level

\begin{tabular}{lccc}
\hline Group & $\boldsymbol{t}$ & $\boldsymbol{d f}$ & Sig. (2-tailed) \\
\hline Aquares model & 6.875 & 59 & .000 \\
\hline
\end{tabular}

\section{Normality Test}

Prerequisite tests which include tests of normality and homogeneity in this study can be seen in Tables 5 and 6 . Before conducting data analysis, it is necessary to meet the analysis requirements to prove that the data are normally distributed. To find out it is proven by the normality test. The findings of the data normality test analysis in Table 5 show that the value of the attitude of personal responsibility both pretest and posttest values are normally distributed. For the value of social responsibility both pretest and posttest values are also normally.

Table 5. Normality Test Data Processing Results

\begin{tabular}{lcccl}
\hline $\begin{array}{l}\text { Experiment Data } \\
\text { Group }\end{array}$ & $\begin{array}{l}\text { Kolmogorov- } \\
\text { Smirnov Test }\end{array}$ & p-value & Distribution \\
\hline Personal & Pre & .457 & $>.05$ & Normal \\
Responsibility & Post & .470 & $>.05$ & Normal \\
Social & Pre & .721 & $>.05$ & Normal \\
Responsibility & Post & .996 & $>.05$ & Normal \\
\hline
\end{tabular}

\section{Homogeneity Test}

Likewise before data analysis, it is necessary to meet the analysis requirements to prove that the data are homogeneous. To find out, it is proven by homogeneity test. The findings of the data homogeneity test analysis in Table 6 are known for the value of the attitude of responsibility both the pretest value and the posttest value, indicating that it is homogeneous distributed. For the value of social behavior both pretest and posttest values, also showed homogeneous distribution.

Table 6. Homogeneity Test Data Processing Results

\begin{tabular}{llccl}
\hline $\begin{array}{l}\text { Kelompok Data } \\
\text { Eksperimen }\end{array}$ & $\begin{array}{c}\text { Levene } \\
\text { Statistic }\end{array}$ & Probability & Varian \\
\hline Personal & Pre & .440 & $>.05$ & Homogen \\
responsibility & Post & .147 & $>.05$ & Homogen \\
Social & Pre & .621 & $>.05$ & Homogen \\
responsibility & Post & .954 & $>.05$ & Homogen \\
\hline
\end{tabular}




\section{Hypothesis Test}

The result of the hypothesis test is presented in Table 7.

\section{The Impact of the Aquares Model on Personal Responsibility}

The results of the paired sample $t$ test calculation on the responsibility variable in Table 7 obtained the value of $t$-count greater than $t$-table. This means that there is a significant difference between the pre test and post test mean scores of students' responsibility attitudes in the Aquares model. This is reinforced by the acquisition of the mean value of t-count. This shows the post test mean value (after the Aquares model treatment was given) is higher and significant than the pre test mean value (the average before treatment was given). Therefore, it can be concluded that the Aquares model has a significant influence on the attitude of responsibility. The influence of the Aquares model was seen in the change in attitude of students, they were more serious in completing their swimming assignments, respecting teacher instructions, participating actively, respecting, and caring for friends. Learning to Respect the rights and feelings of others had three related aspects, namely self-control, the right to resolve conflicts peacefully, and the right of everyone to be included in every activity in the class. The Aquares model developed in this study, modifies the TPSR model so that it was appropriate to measure the personal and social responsibility of primary school students consisting of five variables: respect, participation, self-direction, caring, \& role model.

Table 7. Results Analysis of Paired Sample Tests for Personal and Social Responsibility

\begin{tabular}{|c|c|c|c|c|c|c|c|}
\hline & & \multicolumn{3}{|c|}{ Paired Differences } & \multirow{2}{*}{$t$} & \multirow{2}{*}{$d f$} & \multirow{2}{*}{$\begin{array}{c}\text { Sig. } \\
\text { (2-tailed) }\end{array}$} \\
\hline & & Mean & $S D$ & $S E$ & & & \\
\hline Pair 1 & $\begin{array}{l}\text { Pre test-post test } \\
\text { Personal responsibility }\end{array}$ & -7.137 & 5.385 & .983 & -7.540 & 59 & .000 \\
\hline Pair 1 & $\begin{array}{l}\text { Pre test-post test } \\
\text { Social responsibility }\end{array}$ & -8.321 & 9.352 & 1.707 & -4.631 & 59 & .000 \\
\hline
\end{tabular}

$\mathrm{SD}=$ Standart Deviasi, $\mathrm{SE}=$ Standart Error of Mean

\section{The Impact of the Aquares Model on Social Responsibility}

The results of paired sample t-test calculations on social behavior variables obtained $t$-count values greater than $t$-table. This could be interpreted that there was a significant difference between the pre test and post test mean scores of students' social behavior in the Aquares model. This is reinforced by the acquisition of the mean value of $t$-count showed by Table 7 . This shows the post test mean value (after the treatment of the Aquares model was given) is higher and significant than the pre test mean value (the average before the treatment is given), so it is concluded that the Aquares model has a significant influence on social responsibility. The motion material applied through the Aquares model consist of water recognition, water games, freestyle swimming, backstroke swimming, breaststroke swimming, and water safety, each having a different form of activity in increasing personal and social responsibility. Table 8 shows the form of water activities as part of the Aquares model material.

Table 8. Various Types of Water Activities in the Aquares Model

\begin{tabular}{llll}
\hline Water Orientation & Water Games & Swimming Styles & Water Safety \\
\hline Sit and legs move & "Catch Fish" & Legs motion & Supine motion \\
Prone and legs motions & "Shooting Star" & Arms motion & Stomp on the water \\
Swing arms & "Water Polo" & Breathing & Jump nails \\
Run in the water & "Dragon Snake" & Coordination & Take coins \\
Jumped nails & "Water Pedicab" & Swimming & CPR \\
\hline
\end{tabular}


In addition to statistical evidence, research results were also supported by the actuality of field studies based on observations on the learning process using the Aquares model. Based on observations, groups of students who intervened using the Aquares model showed an increase in their responsibilities, seen from their attitudes during the learning activities. During the learning process at the beginning to the end of the intervention, students showed significant attitude changes. The change in attitude observed during the test showed that students appreciated their friends or teacher who was talking. Students were also willing to work together and be actively involved in the swimming lesson process by helping one another and helping to explain difficult movements. In addition, students could learn independently with their groups in solving problems of learning assignments given by the teacher. They could also motivate one another and showed concern for other friends, especially when their friends had difficulty doing mobile learning tasks.

\section{Discussion}

Increased of personal and social responsibility of students is occured because the Aquares model provides more opportunities for students to integrate responsibility into swimming lesson. The crawl style which is frequently used in national and international competitions. However, this swimming style requires much attention because of its complexity (Subagyo, Guntur, \& Alim, 2020). The forms of water activity chosen in this study indirectly guided students to be able to behave responsibly for themselves and others. The forms of water recognition activities, water games, swimming style, and water safety are very good forms of activities in teaching the attitude of responsibility. So that this water activity is compatible with the TPSR theory developed by Hellison. In this case the relationship between the teacher and students also became more interactive so as to enable verbal persuasion by the teacher against students or also between students and other students. Related to the influence of the Aquares model on the attitude of responsibility and social behavior of students, it can be explained that social responsibility and behavior are formed by the existence of a contract of behavior before learning given by the teacher systematically starting from a simple level to a complete level. This is consistent with the research results which showed an increase in responsibility: consisting of variables of respect, participation, independence, and care for basketball material at Yogyakarta Senior High School (Nurina \& Sukoco, 2014).

Integration in swimming lesson according to Martinek \& Hellison (2016) is done at five levels of behavior that students must achieve gradually in accordance with their abilities. The first level aims to build a positive learning environment, by accustoming mutual respect for the rights and feelings of others, following swimming lessons, obeying the rules in the pool, and being able to control oneself from danger in the pool. The second level deals with participation and endeavoring in learning, motivating yourself to try new things from the swimming movement, and finding out when facing difficulties in learning. The third level, expanding the learning environment by habituating to do the task independently, developing goal setting or directing oneself, instilling swimming skills and opposing all forms of peer pressure. The fourth level is getting used to helping each other, caring for friends who are not good at swimming, not easily offended, and able to empathize. The fifth level is to familiarize the four levels that have been done and try to apply it to other arenas of life such as the family environment, neighborhoods, and the wider community, as well as trying to be an example and be able to implement positive behavior (Elias, 2005).

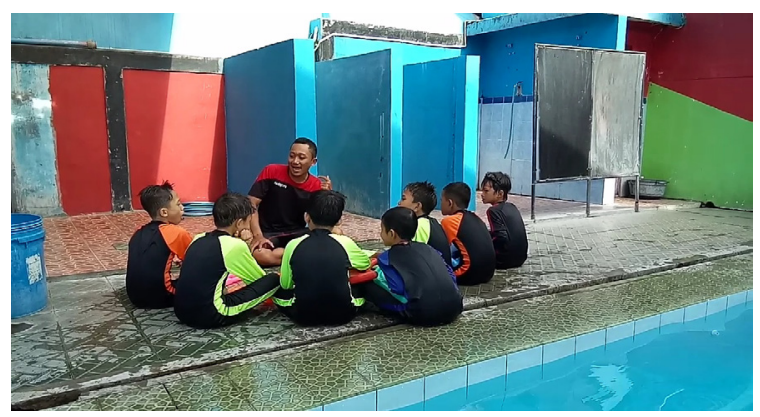

Figure 1. Task Explanation by Teacher and Respect Process by Students

The Figure 1 explains one of the important stages in the implementation of the Aquares model, namely awareness talk. The teacher explains what tasks will be performed and students pay homage to what the teacher says. 
The influence of the Aquares model could be seen in the changes in the attitude of students, they were more respectful, there was no noise, could listen and paid attention when the teacher was setting an example. The attitude of students was also shown by the feeling of courage to do the swimming movements even though they were in a deep pool and there was no excessive fear. Another attitude that arises was caring for friends who had not been able to do the correct swimming movements. The culmination of the success of the Aquares model in swimming lesson is that all attitudes that has been obtained serve as examples in other environments, both in homes, schools, and in social relationships. Therein lies the highest level of the developed TPSR theory, which is to become a role model for others and elsewhere. Respect for others is intended to provide a psychologically and physically safe place for all students and to deal with students who need to deal with issues of self-control and respect.

Learning to respect the rights and feelings of others has three related aspects, namely selfcontrol, the right to resolve conflicts peacefully, and the right of everyone to be involved in every activity. The self-control can be started by trying to control selfish behavior and students become more sensitive to the feelings of others (Hellison \& Walsh, 2002). The ability to resolve conflict resolution helps students learn the value of peaceful and democratic conflict resolution. Another aspect is that all students have the right to be included in other activities, this means that all students are eligible to be included in class activities whether they are skilled and regardless of gender, race, ethnicity, or physical level. This attitude of personal and social responsibility arises during swimming lesson which indeed upholds the principle of responsibility of primary school students.

\section{The Impact of the Aquares Model on Personal Responsibility}

The essence of the expected Aquares model, shows that to succeed in their social environment, students must learn to be responsible for themselves and be responsible for others, and determine ways to control themselves, so that they can be accepted by their environment (Escartí, 2012). The Aquares model gradually familiarizes students in behaving and behaving which will help them to become responsible and able to control themselves (Cabalero et al., 2013). Based on the previous explanation, the Aquares model is an appropriate learning tool in teaching skills as well as behaving responsibly towards themselves and others and being able to control themselves. The Aquares model concept includes a form of effort to respect the rights and feelings of others, to participate, to direct oneself as social people who care and help others. In sports, TPSR has a long history of improving "good character" (Gordon, Jacobs, \& Wright, 2016).

Research on the TPSR model in PE has increased over the last two decades (Lee \& Choi, 2015). Traditionally, the application of the TPSR model has most often taken place in after-school or community-based programmes with voluntary participation and a small number of participants. In conclusion, for many physical educators, the TPSR model is considered to be a viable and effective pedagogical approach to the teaching of PE. The purpose of this systematic review is to analyse the studies included in peerreviewed journals of the TPSR model within the PE context (Pozo et al., 2018).

The results also showed that the Aquares model given to class had a significant influence in increasing students' personal and social responsibility. Social responsibility can be increased through the TPSR program by using specific strategies in physical education (Salamuddin \& Harun, 2010). The Aquares model has increased students' respect, this was demonstrated by the way students listened to other people, not made a fuss, and paid attention when the teacher or other students gave examples of swimming movements that must be done. Collaboration and self-direction were shown by students when they played game material "catching fish", "shooting stars", "water polo", and various other types of water games. The Aquares model is believed to increase students' personal and social responsibility in aspects of self-control, effort, helping others, self-direction, cooperation, communication skills, interpersonal relationships, feelings of responsibility, and sportsmanship (Hellison \& Walsh, 2002). Positive changes in motivation and active participation were also shown when students practiced swimming-style learning practices, this could be seen from the enthusiasm 
and motivation of students in completing a mutually agreed exercise program. Material freestyle swimming, backstroke style, and breaststroke style taught students to exert selfdirecting efforts in completing the swimming distance that must be traveled. Changes in students' responsibilities were also shown by increasing sensitivity to friends and the environment, students showed concern and were willing to help others in helping swimming material. Caring and willingness to help others was shown when other students get into trouble, and they help voluntarily.

\section{The Impact of the Aquares Model on Social Responsibility}

The results of previous studies have explained that the TPSR-based learning model is an effective learning model for the development of students' social responsibility and behavior (Escartí, Gutiérrez, Pascual, \& Marín, 2010). The influence of the Aquares model on social behavior is shown by the caring attitude of students in helping friends who have difficulty learning swimming. Help friends who are victims of accidents in the pool like drowning or almost drowning. The highest value of social attitudes is shown by being a role model not only for other friends but also in other places or in other environments. Swimming lesson materials wrapped in the Aquares model prove to have been able to improve students' social attitudes. The movements in swimming material help in the form of float exercises, helping victims, helping friends, and simulating Cardio Pulmonary Resuscitation (CPR) have formed high social attitudes in students. Swimming material helps or water safety develops empathy attitude of students so that it teaches high social behavior. The material for helping swimming is different from the material in other physical education classes, remembering that swimming helps is very important as a provision for students to face challenges in the water environment.

According with Martinek \& Hellison (2016) opinion that specific instruction strategies include direct instruction, group discussions, peer instruction, learning to work together, work independently, self-reflection, and make their own decisions. Provide opportunities to integrate responsibilities into learning and enhance the active role of students all the time.
From the description above it can be seen that the Aquares learning model integrates the formation of positive behavior into swimming learning, which in turn, increases positive behavior and supports academic improvement of students (Anthony et al., 2009). According to Li, Wright, Rukavlna, \& Pickering (2008), educational success depends not only on academic potential, but also on the ability of students to relate respectfully and be accountable to others. The TPSR model is considered an ideal framework for designing physical education classes and the whole school curriculum. The basic concept of the TPSR model is to develop the principles and processes of positive youth development (Beale, 2016). In its implementation, the TPSR model focuses on students achieving five main objectives (Gordon et al., 2016), namely: respect (Level 1), participation or effort (Level 2), selfdirection (Level 3), caring (Level 4), and (Level 5 ), where students can apply these skills outside the classroom in daily life.

There are five stages of TPSR which are then developed into the Aquares model: counseling time, awareness talk, the lesson, group meetings, and reflection time (Martinek \& Hellison, 2016). Counseling time is the amount of time needed by the teacher in preparing learning. The task of the teacher when the teaching and learning process takes place is to provide an explanation of the stages, placing students, directing important moments in learning. Awareness talk is a session to remind students about the responsibilities they want to achieve, and in this session students can make contracts with teachers about the target level of responsibility that will be achieved in learning that day. Lesson focus is most of the learning time used in the core of the exercise. During this session, the teacher uses certain instructional strategies to integrate responsibilities into swimming learning. Group meetings are a practical learning tool for students to learn democratic values, this session aims to provide opportunities for students to express their views about the learning process at the time, about their classmates, and how effective the instructional instructions delivered by the teacher. An important goal to be achieved in this group meeting is to provide practical experience to students about the process of making decisions in the group and how they should behave when they get different perceptions. Reflection time 
the final session of Aquares model is reflection time which is done before the students leave the class. Reflection time is designed so that students reflect and evaluate how much they respect the rights and feelings of others, how effort and participation they show during the learning process, and the possibility of applying the target attitudes of students' responsibilities outside the swimming lesson.

Implementing the Aquares model, can help students take responsibility for their own behavior and understand what it means to demonstrate that behavior. The foregoing means that the developed Aquares model has demonstrated a positive influence on the responsibilities of elementary school students. This is indicated by the increasing variable respect, participation, self-direction, caring, and role model. The results of this study are relevant to the use of the TPSR model in physical education that has been studied and applied in several countries that show positive progress. The relevance can be seen from the results of research applied to physical education classes (Beaudoin, 2012; Gordon, Thevenard, \& Hodis, 2011; Hassandra \& Goudas, 2010; Jung \& Wright, 2012). This indication is relevant to the fact that the formation of social responsibility cannot be done instantly, but it takes a long and continuous time (Irmansyah, Sugiyanto, Lumintuarso, \& Sukoco, 2020).

The results of this study were relevant to the use of the TPSR model in physical education and have been studied and applied in many countries (such as: USA, Canada, New Zealand, South Korea, and Spain). The following are some of the results of the relevant TPSR research: Research results applied to the extracurricular program (Cryan \& Martinek, 2017; Gordon et al., 2016). Research results applied to communitybased projects (Buchanan, 2001; Wright et al., 2012). Research results applied to sports (Walsh, Ozaeta, \& Wright, 2010).

From the relevant research, the results showed that the TPSR model had positive results for young people. A review of 26 studies that tested the effectiveness of the TPSR model on positive youth development found that 19 studies resulted in increased respect, effort, independence, care and capacity for leadership among athletes and physical education students (Hellison \& Walsh, 2002). More recent research results from 22 studies of TPSR-based programs in physical education classes conclude that successful implementation of TPSR contributes to a series of positive behavioral, social, emotional, psychological, and educational outcomes (Pozo et al., 2018). For example, studies show an increase in effort, empathy, independent learning, leadership skills, caring, teamwork, and personal \& social responsibility, as well as a reduction in behavioral problems, such as violence against peers and absence from school (Beale, 2016; Jacobs, Castaneda, \& Castaneda, 2016; Taylor, Oberle, Durlak, \& Weissberg, 2017).

The findings related to teachers show that: (a) teachers should provide opportunities for success to students, set expectations, and create a close and respectful relationship with their students; and (b) the strategies used by teachers were perceived as positive. Moreover, their prejudices and preconceptions about at-risk students changed because the Aquares model required them to have a close relationship with the students.

The findings from this Aquares model review indicate the following implications that the PE content should be aligned with the programme levels and cultural differences between participants, as well as students' lack of motivation, may be barriers to developing the Aquares model. The Aquares model at an early age is beneficial, especially because of the involvement in the teaching process of the physiological resources of children as well as the pedagogical ones of the teachers/trainers. The Aquares model provides a good framework in terms of forming student responsibility.

\section{CONCLUSION}

Based on the results of data processing and data analysis, it can be concluded that the Aquares model developed from the Teaching Personal and Social Responsibility (TPSR) theory had an impact on students' personal and social responsibility in swimming lesson. This attitude appeared in increasing aspects: respect, participation, self-direction, caring, and role models. The Aquares model implemented in this study provided a strong framework for creating a positive and meaningful environment in swimming lesson. The results of this study were relevant to the use of the TPSR model in 
physical education and have been studied and applied in several countries that show positive progress. The limitations of this study were first, not all teachers understand the concept of responsibility learning according to the Aquares model. Second, the swimming skills of students who were heterogeneous, some were already skillfull and some were not yet. Third, the Aquares model experiment could only be done in schools that have intensive swimming class programs, for that it takes quite a long time and the costs were not cheap. Further research is needed to obtain the impact of physical activities on responsibilities.

\section{ACKNOWLEDGMENT}

On this occasion, researchers would like to thank the Director of Postgraduate, Yogyakarta State University for giving permission to conduct research and using infrastructure. We also would like to thank the principal of Yogyakarta Luqman Al Hakim Primary School for their willingness to use students in this study. Last but not least, we also would like to thank the Editor and all administrators of the Journal of Cakrawala Pendidikan for providing a platform for scientific communication.

\section{REFERENCES}

Alcalá, D., Río, J., Calvo, G., \& Pueyo, Á. (2019). Comparing effects of a TPSR training program on prospective $\mathrm{PE}$ teacher's in Spain, Chile and Costa Rica. Physical Education and Sport Pedagogy, 24(3), 220-232. https://doi.org/10.1080/1 7408989.2018 .1561837 .

Anthony, E., Alter C., \& Jenson, J. (2009). Development of a risk and resilience-based out-of-school time program for children and youths. Social Work, 54(1), 45-55. https://doi.org/10.1093/sw/54.1.45.

Beale, A. (2016). Making a different TPSR, a new wave of youth development changing lives one stroke at a time. Journal of Physical Education, Recreation \& Dance, 87(5), 31-34. https://doi.org/10.1080/073 03084.2016 .1157392 .

Beaudoin, S. (2012). Using responsibilitybased strategies to empower in-service Physical Education and health teachers to learn and implement TPSR. Agora para la educación física y el deporte, 14(2), 161-177. http://uvadoc.uva.es/ handle/10324/23736.

Buchanan, A. (2001). Contextual challenges to teaching responsibility in a sports camp. Journal of Teaching in Physical Education, 20(2), 155-171. https://doi. org/10.1123/jtpe.20.2.155

Cabalero, P., Delgado, M., \& Escartí, A. (2013). Analysis of TPSR model-based programmes applied in USA \& Spain. Revistas Journal of Human Sport \& Exercise, 8(2), 427-441. https://doi. org/10.4100/jhse.2012.82.10.

Cryan, M., \& Martinek, T. (2017). Youth sport development through soccer: Anevaluation of an after-school program using the TPSR model. The Physical Educator, 74(1), 127-149. https://doi. org/10.18666/tpe-2017-v74-i1-6901.

Elias, M. J. (2005). The connection between academic and socialemotional learning. In The Fundamental Connection of Sel/Ei, Academic Performance, and the Process of Learning, pp. 4-14.

Escartí, A. (2012). Applying the teaching personal and social responsibility model (TPSR) in Spanish schools context: Lesson learned. Agora para la educación fisica y el deporte. 14(2), 178-196.

Escartí, A., Gutiérrez, M., Pascual, C., \& Marín, D. (2010). Application of Hellison's teaching personal and social responsibility model in physical education to improve self-efficacy for adolescents at risk of dropping-out of school. The Spanish Journal of Psychology, 13(2), 667-676. https://doi.org/10.1017/ S113874160000233X.

Escartí, A., Goig R., \& Wright, P. M. (2017). Assesing the implementation fidelity of a school-based teaching personal and social responsibility program in PE. Journal of Teaching in Physical Education, 37(1), 12-23. https://doi.org/10.1123/jtpe.20160200 . 
Glassman, T., Castor, T., Karmakar, M., Blavos, A., Dagenhard, P., Domigan, J., \& Kucharewski,R.(2018).Asocialmarketing intervention to prevent drowning among inner-city youth. Health Promotion Practice, 19(2), 175-183. https://doi. org/10.1177/1524839917732559.

Gordon, B., Thevenard, L., \& Hodis, F. (2011). Teaching personal and social responsibility through secondary school physical education: The New Zealand experience. New Zealand Physical Educator, 44(1), 25-37. https://www.srknowledge.org.nz/ research-completed/teaching-personaland-social-responsibility-throughsecondary-school-physical-educationthe-new-zealand-experience/.

Gordon, B., Jacobs, J., \& Wright, P. (2016). Social and emotional learning through a teaching personal and social responsibility based after-school program for disengaged middle-school boys. Journal of Teaching in Physical Education, 35(4), 358-369. https://doi.org/10.1123/jtpe.2016-0106.

Hassandra, M. \& Goudas, M. (2010). An evaluation of a physical education program for development of stundents responsibility. Hellenic Journal of Psychology, 7(3), 275-297.

Hellison, D. \& Walsh, D. (2002). Responsibilitybased youth programs evaluation: Investigating the investigations. Quest, 54(4), 292-307. https://doi.org/10.1080/0 0336297.2002.10491780.

Irmansyah, J., Sugiyanto, Lumintuarso, R., \& Sukoco, P. (2020). Children's social skill through traditional sport games in primary school. Cakrawala Pendidikan, 39(1), 39-53. https://doi.org/10.21831/ cp.v39i1.28210.

Jacobs, J. M., Castaneda, A., \& Castaneda, R. (2016). Sport-based youth and community development: Beyond the ball in Chicago. Journal of Physical Education, Recreation \& Dance, 87(5), 18-22. https://doi.org/10 $.1080 / 07303084.2016 .1157386$.

Jung, J. \& Wright, R. (2012). Application of
Hellison's responsibility model in South Korea: A multiple case study of 'atrisk' middle school students in physical education. Agora para la educación física $y$ el deporte, 14(2), 140-160.

Kumar, V., Singh, A., Sandhu, J. S., Gupta, N., \& Pandey, R. M. (2017). Comparative study of sports motivation among contact and non-contact sports persons. International Journal of Physical Education, Sports and Health, 4(4), 128-131. www.kheljournal. com.

Lee, O., \& Choi, E. (2015). The influence of professional development on teachers' implementation of the teaching personal and social responsibility model. Journal of Teaching in Physical Education, 34(4), 603-625. https://doi.org/10.1123/ jtpe.2013-0223.

Li, W., Wright, P., Rukavlna, \& Pickering, M. (2008). Measuring students perceptions of personal and social responsibility and the relationship to intrinsic motivation in urban physical education. Journal of Teaching in Physical Education, 27(2), 167-178. https://doi.org/10.1123/ jtpe.27.2.167.

Martinek, T. \& Hellison, D. (2016). Teaching personal and social responsibility: Past, present and future. Journal of Physical Education, Recreation \& Dance, 87(5), 8-13. https://doi.org/10.1080/07303084.2 016.1157382 .

Nurina, T., \& Sukoco, P. (2014). Upaya peningkatan karakter siswa dalam permainan bola basket melalui model TPSR. [The efforts to improve characters of senior high school students in basketball game through TPSR model]. Jurnal Keolahragaan, 2(1), 77-87. https://doi. org/10.21831/jk.v2i1.2605.

Petrass, L.A., \& Blitvich, J. D. (2014). Preventing adolescent drowning: Understanding water safety knowledge, attitudes and swimming ability. The effect of a short water safety intervention. Accident Analysis and Prevention, 70(2014), 188-194. https://doi.org/10.1016/j. 
aap.2014.04.006.

Pozo, P., Grao-Cruces, A., \& Pérez-Ordás, R. (2018). Teaching personal and social responsibility model-based programmes in physical education: A systematic review. European Physical Education Review, 24(1), 56-75. https://doi. org/10.1177/1356336X16664749.

Rahayu, N. I., Suherman, A., \& Jabar, B. A. (2018). Hybridising teaching personal social responsibility (TPSR) and problem based learning (PBL) in Physical Education. Jurnal Pendidikan Jasmani dan Olahhraga, 3(2), 101-111. https://doi. org/10.17509/jpjo.v3i2.12395.

Salamuddin, N., \& Harun, M. T. (2010). Facilitating the process of learning social skills through humanistic physical education. Procedia - Social and Behavioral Sciences, 9(2010), 223-227. https://doi.org/10.1016/j. sbspro.2010.12.140.

Schwebel, D. C., Jones, H. N., Holder, E., \& Marciani, F. (2011). The influence of simulated drowning audits on lifeguard surveillance and swimmer risk-taking at public swimming pools. International Journal of Aquatic Research and Education, 5(2), 210-218. https://doi. org/10.25035/ijare.05.02.08.

Subagyo, S., Guntur, G., \& Alim, A. (2020). Swimming crawl style: The effect of pure progressive method and level of body fat. Cakrawala Pendidikan, 39(1), 183-190. https://doi.org/10.21831/cp.v39i1.27553.

Sutapa, P. \& Suharjana, S. (2019). Improving gross motor skills by gross kinesthetic-and contemporary-based physical acctivity in early childhood. Cakrawala Pendidikan, 38(3), 540-551. https://doi.org/10.21831/ cp.v38i3.25324.

Taylor, R. D., Oberle, E., Durlak, J. A., \& Weissberg, R. P. (2017). Promoting positive youth development through school-based social and emotional learning interventions: A meta-analysis of follow- up effects. Child Development, 88(4), 1156-1171. https://doi.org/10.1111/ cdev. 12864.

Umegaki, A., Otomo, S., Minamishima, E., Ueta, K., Fukada, N., Yoshii, T., \& Miyao, N. (2016). Study of the transfer and maintenance of the effects of the TPSR model in junior high school physical education classes. Taiikugaku Kenkyu (Japan Journal of Physical Education, Health and Sport Sciences), 61(2), 503-516. https://doi.org/10.5432/ jjpehss.15069.

Walsh, D. (2008). Helping youth in underserved communities envision possible futures: An extension of the teaching personal and social responsibility model. Research Quarterly for Exercise and Sport, 79(2), 209-221. https://doi.org/10.1080/0270136 7.2008.10599484.

Walsh, D., Ozaeta, J., \& Wright, P. M. (2010). Transference of responsibility model goals to the school environment: Exploring the impact of a coaching club program. Physical Education and Sport Pedagogy, 15(1), 15-28. https://doi. org/10.1080/17408980802401252.

Wright,P.M.,\&Burton, S.(2008).Implementation and outcomes of a responsibility-based physical activity program integrated into an intact high school physical education class. Journal of Teaching in Physical Education, 27(2), 138-154. https://doi. org/10.1123/jtpe.27.2.138

Wright, P. M., \& Craig, M. W. (2011). Tool for assessing responsibility-based education (TARE): Instrument development, content validity, and inter-rater reliability. Measurement in Physical Education and Exercise Science, 15(3), 204-219. https://doi.org/10.1080/109136 7X.2011.590084.

Wright, E., Withley, M., \& Sabolboro, G. (2012). Conducting a TPSR program for an underserved girls' summer camp. Agora Para La Educación Física y El Deporte, 14(1), 5-24. 